\title{
Research on the Regional Logistics Index System of Sustainable Development
}

\author{
Xiuhua Li* \\ School of Economics and Management \\ Beijing Jiaotong University \\ Beijing, China \\ lixiuhua-23@163.com \\ *Corresponding author
}

\author{
Yuan Tian \\ School of Economics and Management \\ Beijing Jiaotong University \\ Beijing, China \\ Tianmengfei@126.com
}

\author{
Hui Tang \\ School of Economics and Management \\ Beijing Jiaotong University \\ Beijing, China \\ tangqianlan11@126.com
}

\begin{abstract}
The development of logistics has experienced from the enterprise internal management to integrated enterprise internal departments and then to the external integration among enterprises of the three stage. In this development process, people focus on the factors of productivity, efficiency and cost associated with economic benefits, while ignoring the logistics activities cause the ecological environment destruction caused by the "external negative effect", such as waste gas pollution, noise pollution, waste of resources, traffic congestion and waste, carbon dioxide emissions, etc. Thus, it caused the people from simply considering logistics economic benefit factors to comprehensive consideration of economic, social and environmental factors, and then formed the sustainable development of the logistics mode. Through the logistics index we can more effectively analyze regional macroeconomic trends and regional economic ties outside. It is also an important indicator of regional economic development.
\end{abstract}

Keywords-sustainable development; regional logistics; index system

\section{INTRODUCTION}

With the development of human society, we face more and more severe challenges, especially the population expansion, environmental degradation and resource shortage, which has become the major issues of common concern to the governments and people. The logistics has been the pillar of the social economy, and its contribution to the social and economic development is an indisputable fact. But on the other hand, the logistics also consumes resources and energy, and cause serious damage to the environment, such as waste water, waste and noise. If not improve these problems, it must will bring many negative effects to the sustainable development of the society. Therefore, the logistics industry should put the "sustainable development" as the principle of senior best interests.

\section{INDEX OF REGIONAL LOGISTICS}

\section{A. Regional Logistics Index Concept}

Regional logistics index ${ }^{[1]}$ refers to the logistics activity system evaluation index, which fully support the goal of region sustainable development, adapt to the regional environmental characteristics, have a reasonable spatial structure and scale of services, and realize the effective organization and management. And it is a comprehensive diagnosis of logistics industry development and the necessary means of logistics management.

The sustainable development of regional logistics ${ }^{[2]}$ refers to a certain geographical areas of sustainable development, which involved resources, environment, economy and society and other fields. Coordinating the relationship between environment and development to make the social and economic development satisfy the needs of modern people, through adjusting the logistics industry structure and reasonable layout, using new technology, making cleaner production and civilized consumption, improving the efficiency of the use of resources, and reducing waste emissions.

\section{B. Additional Information Required by the Volume Editor}

The establishment of the index of regional logistics has the very vital significance to operate and optimize the regional logistic industry development and management $\operatorname{mode}^{[3]}$.

Firstly, regional logistics index can objectively reflect the current logistics market. Establish and publish regional logistics index will make the logistics market more mature and standard.

Secondly, the index of regional logistics is the guide of the regional logistics enterprises to invest and manage, which will help the logistics enterprises of this region to set a reasonable management pattern. 
Finally, the establishment of the index of regional logistics is conducive to the healthy sustainable development of regional logistics industry; and it is advantageous to the government guide and logistics enterprise management in macroscopic level.

\section{THE ESTABLISHMENT OF SUSTAINABLE DEVELOPING REGIONAL LOGISTICS INDEX SYSTEM}

Regional logistics index system show ${ }^{[4][5]}$ in Figure I .

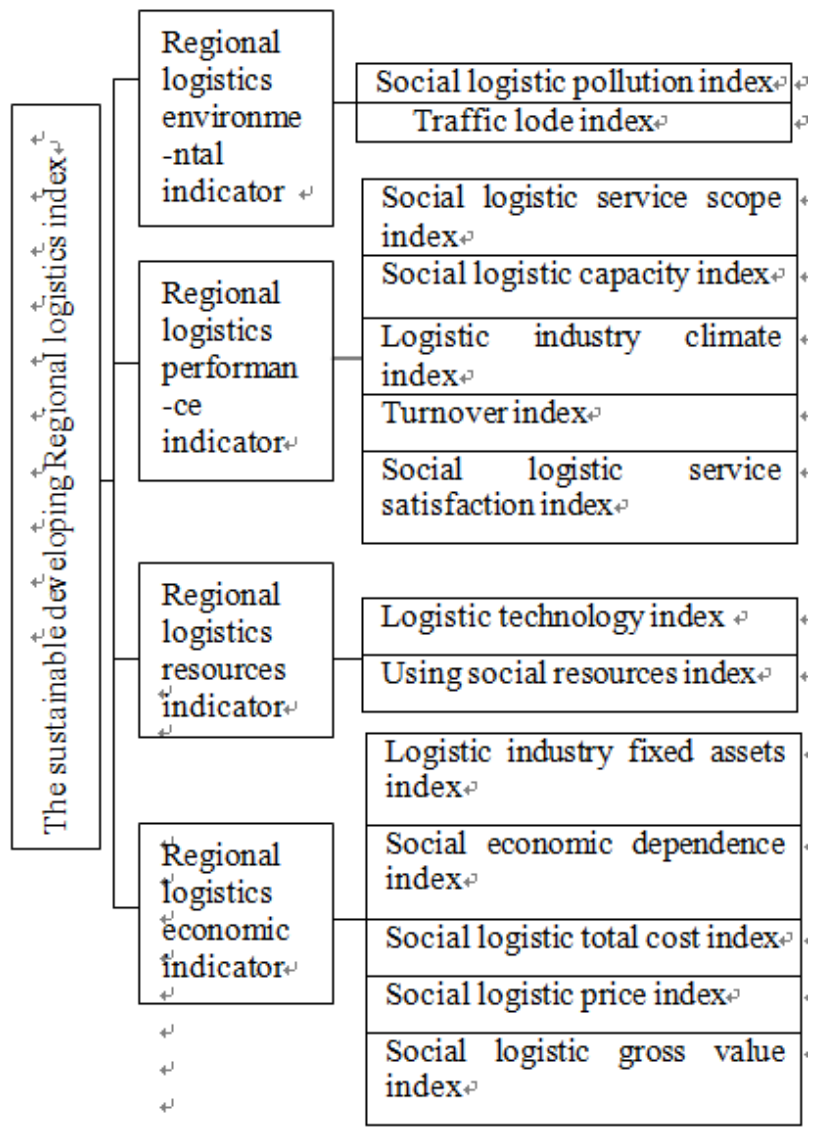

FIGURE I. REGIONAL LOGISTICS INDEX SYSTEM

\section{MOdEL AND CASE}

With the development of logistics industry, the use of resources and environmental pollution becomes more and more serious. Therefore, through establishing the sustainable developing regional logistics index system and using fuzzy analytical hierarchy process, to help the identification of regional logistics development present situation, and find out the right development direction, in order to make economy healthy, sustainable develop. Existing domestic city A develops tourism, its population less than one million, and logistics industry has rapidly developed in recent years. In order to verify the sustainability of the regional logistics development, now use the mathematical method to evaluate, and then eventually determine the science of development.

\section{A. Principle of Fuzzy Analytic Hierarchy Process}

Fuzzy comprehensive evaluation method use the fuzzy concept $^{[6][7]}$ to evaluate objects, and described by excellent, good, poor, very poor. Its disadvantage is that the weight of each evaluation index distribution affected by human factors, and can not accurately and objectively reflect the practical importance. Analytic hierarchy process can solve the problems of the human factors influence, through comparing to determine the relative important degree of hierarchy index, and then make a comprehensive evaluation. Analytic hierarchy process is more objective and accurate distribution of the weight of each evaluation index, while fuzzy evaluation method is relatively subjective, and it can solve the problem of objective cannot solve. So, combining the advantages of two methods make more reasonable and effective evaluation and selection.

Fuzzy analytic hierarchy process mainly involves four elements: factor set $\mathrm{U}$, evaluation set $\mathrm{V}$, the single factor evaluation matrix and weight vector $\mathrm{W}$. First determine the evaluation factor set $\mathrm{U}$. $\mathrm{U}=\{\mathrm{U} 1, \mathrm{U} 2, \mathrm{U} 3, \ldots \ldots, \mathrm{Un}\}$, $\mathrm{U} 1=\{\mathrm{U} 11, \mathrm{U} 12, \ldots . . \mathrm{U} 1 \mathrm{~m}\}, \ldots . . . \mathrm{Un}=\{\mathrm{Un} 1, \mathrm{Un} 2, \ldots \ldots . . \mathrm{Unm}\}$.

Step 1: Determine the evaluation factors weight vector W. Set up analytic hierarchy model, find out the relative important degree of the evaluation factors, and then compare judgment matrix constructed. As Table I

TABLE I. FACTOR SCALE TABLE

\begin{tabular}{|c|l|l|}
\hline $\begin{array}{c}\text { Relative } \\
\text { Importancea } \\
\text { ij }\end{array}$ & \multicolumn{1}{|c|}{ Definition } & \multicolumn{1}{|c|}{ Illustration } \\
\hline 1 & EquallyImportant & $\begin{array}{l}\text { factor i\&j has the same } \\
\text { importance }\end{array}$ \\
\hline 3 & Little Important & $\begin{array}{l}\text { factor i comparej, little } \\
\text { important }\end{array}$ \\
\hline 5 & Important & factor i comparej, Important \\
\hline 7 & Clearly Important & $\begin{array}{l}\text { factor i comparej, Clearly } \\
\text { Important }\end{array}$ \\
\hline 9 & Absolutely Vital & $\begin{array}{l}\text { factor i comparej, Absolutely } \\
\text { Vital i comparej, the } \\
\text { between the }\end{array}$ \\
\hline $2 、 4 、$ & Intermediatevalues & $\begin{array}{l}\text { factor i } \\
\text { importance } \\
\text { above two adjacent levels }\end{array}$ \\
\hline
\end{tabular}

Step 2: Whether the weight is reasonable has a direct impact to the accuracy of the results, so consistency check is required. $\mathrm{CR}=\mathrm{CI} / \mathrm{RI}$, if $\mathrm{CR}<0.1$, it satisfies the requirement of consistency, and $\mathrm{W}=\mathrm{Wn}(\mathrm{W} 1, \mathrm{~W} 2, \mathrm{~W} 3, \ldots)$.

Step 3: Set up evaluation set $\mathrm{V}$ and score vector E, Assume that

$\mathrm{V}=(\mathrm{V} 1, \mathrm{~V} 2, \mathrm{~V} 3, \mathrm{~V} 4, \mathrm{~V} 5)=($ very good, good, common, poor, very poor), equivalent $\mathrm{E}=(5,4,3,2,1)$.

Step 4: According to the expert evaluation of various factors, get the single factor fuzzy evaluation matrix R. And determine the vector of the scheme by fuzzy comprehensive evaluation, $\mathrm{B}=\mathrm{W} \mathrm{O} \mathrm{R}, \mathrm{O}$ is fuzzy operator.

Step 5: Evaluation indicators layer: $\mathrm{Bi}=\mathrm{Wi} * \mathrm{Ri}$, then get comprehensive evaluation matrix B. 
Step 6: Comprehensive evaluation of target layer: calculate comprehensive evaluation value of each scheme, $\mathrm{S}=\mathrm{BTE}$.

In general, different areas in the actual evaluation process may face different demands of the development. Then choose different evaluation system in different regions, set up different fuzzy hierarchy models.

\section{B. Example Profiles}

The data of this instance comes from the city's information called A. In order to guarantee A have a sustainable process of logistics development, mainly consider the regional economy, resources and environment, logistics efficiency four main points. Now need to determine final sustainable development degree by mathematical methods of evaluation.

\section{Determine the Evaluation Factors Set}

Based on theory analysis, get index system as figure II .

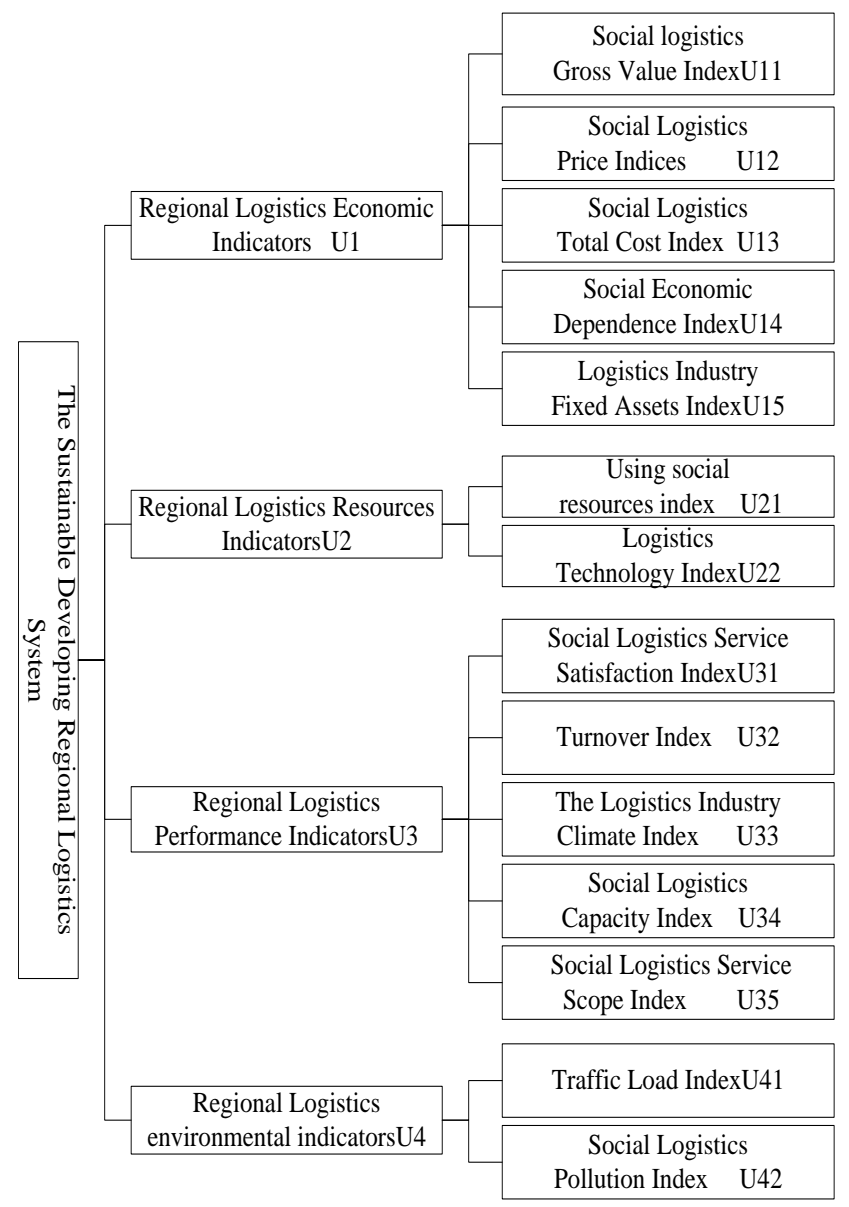

FIGURE II. THESUSTAINABLE DEVELOPING REGIONAL LOGISTICS SYSTEM

\section{Calculation Based on Fuzzy Analytic Hierarchy Process}

Step 1: Establish Judgment Matrix. According to the index system and expert scoring, using the nine scales method, established between the following judgment matrix of each index factors.

$$
\mathrm{A}=\begin{aligned}
& U 1 \\
& U 2 \\
& \mathrm{U} 3 \\
& \mathrm{U} 4
\end{aligned}\left[\begin{array}{cccc}
1 & 1 / 2 & 1 / 3 & 2 \\
2 & 1 & 2 & 3 \\
3 & 1 / 2 & 1 & 2 \\
1 / 2 & 1 / 3 & 1 / 3 & 1
\end{array}\right]
$$

1) Make A normalized.

$$
\begin{aligned}
b_{i j}=a_{i j} / \sum_{k=1}^{n} a_{k j}(1) & \\
\text { A1 } & =\left[\begin{array}{c}
0.15,0.22,0.08,0.25 \\
0.31,0.43,0.53,0.375 \\
0.46,0.22,0.26,0.25 \\
0.08,0.13,0.13,0.125
\end{array}\right]
\end{aligned}
$$

2) Row sum. $\boldsymbol{i}=1,2 \ldots, \mathrm{n}$.

$$
v_{i}=\sum_{j=1}^{n} b_{i j}(2)
$$

$$
\mathrm{A} 2=[0.7,1.645,1.19,0.465]
$$

3) Make $\boldsymbol{V}_{\boldsymbol{i}}$ normalized, get $\boldsymbol{W}_{i \text {. }}, \boldsymbol{i}=1,2 \ldots, \mathrm{n}$.

$$
\begin{aligned}
& \mathrm{w}_{\mathrm{i}}=\frac{\mathrm{v}_{\mathrm{i}}}{\sum_{\mathrm{i}=1}^{\mathrm{n}} \mathrm{v}_{\mathrm{i}}}(3) \\
& \quad \mathrm{W}=[0.175,0.411,0.2975,0.116]
\end{aligned}
$$

4)

$$
\begin{aligned}
& \text { Get } \lambda_{\max } \\
& \begin{aligned}
\mathrm{AW} & =\left[\begin{array}{cccc}
1 & 1 / 2 & 1 / 3 & 2 \\
2 & 1 & 2 & 3 \\
3 & 1 / 2 & 1 & 2 \\
1 / 2 & 1 / 3 & 1 / 3 & 1
\end{array}\right]\left[\begin{array}{c}
0.175 \\
0.411 \\
0.2975 \\
0.116
\end{array}\right]=\left[\begin{array}{c}
0.7115 \\
1.704 \\
1.26 \\
0.4892
\end{array}\right] \\
\lambda_{\text {max }} & =\sum_{i=1}^{n} \frac{\sum_{j=1}^{n} a_{i j} w_{j}}{n w_{i}} \\
& =\frac{1}{4}\left(\frac{0.7115}{0.175}+\frac{1.704}{0.411}+\frac{1.26}{0.2975}+\frac{0.4892}{0.116}\right) \\
& =4.17
\end{aligned}
\end{aligned}
$$

Step 2: Consistency Check.

$$
C . I=\frac{\lambda_{\max }-\mathrm{n}}{n-1}=\frac{4.17-4}{4-1}=0.06 \leq 0.1
$$

That passes the consistency check. In the same way, we can get other index weight values:

$\mathrm{W}=(0.175,0.411,0.2975,0.116)$

$\mathrm{W} 1=(0.195,0.124,0.350,0.056,0.275)$

$\mathrm{W} 2=(0.7,0.3)$

$\mathrm{W} 3=(0.411,0.095,0.047,0.235,0.212)$

$\mathrm{W} 4=(0.4,0.6)$

They all pass the consistency check. As Table II : 
TABLE II. RELATIVE WEIGHTS OF REGIONAL LOGISTICS EVALUATION INDEXES FOR SUSTAINABLE DEVELOPING

\begin{tabular}{|c|c|c|c|c|}
\hline $\begin{array}{c}\text { The 1st } \\
\text { Layer } \\
\text { Evaluation } \\
\text { Factors }\end{array}$ & $\begin{array}{l}\text { The 1st } \\
\text { Layer } \\
\text { Evaluat- } \\
\text { ion } \\
\text { Factors } \\
\text { Weight }\end{array}$ & $\begin{array}{c}\text { The 2nd } \\
\text { Layer } \\
\text { Evaluation } \\
\text { Factors }\end{array}$ & $\begin{array}{l}\text { The2nd } \\
\text { Layer } \\
\text { Evaluation } \\
\text { Factors } \\
\text { Weight }\end{array}$ & $\begin{array}{c}\text { The } \\
\text { 2nd } \\
\text { Layer } \\
\text { Evalu- } \\
\text { ation } \\
\text { Factor- } \\
\text { s } \\
\text { Weigh- } \\
\text { ts on U }\end{array}$ \\
\hline \multirow{5}{*}{$\begin{array}{l}\text { Regional } \\
\text { Logistics } \\
\text { and } \\
\text { Economic }\end{array}$} & \multirow{5}{*}{0.388} & $\begin{array}{c}\text { The Total } \\
\text { Social } \\
\text { Logistics }\end{array}$ & 0.195 & 0.076 \\
\hline & & $\begin{array}{c}\text { Social } \\
\text { Logistics } \\
\text { Prices }\end{array}$ & 0.124 & 0.048 \\
\hline & & $\begin{array}{c}\text { Total Cost of } \\
\text { Social } \\
\text { Logistics }\end{array}$ & 0.35 & 0.136 \\
\hline & & $\begin{array}{c}\text { Economic } \\
\text { Dependence }\end{array}$ & 0.056 & 0.022 \\
\hline & & $\begin{array}{c}\text { Investment in } \\
\text { Logistics } \\
\text { Industry }\end{array}$ & 0.275 & 0.107 \\
\hline \multirow{2}{*}{$\begin{array}{l}\text { Regional } \\
\text { Logistics } \\
\text { Resources }\end{array}$} & \multirow{2}{*}{0.235} & $\begin{array}{l}\text { Use Social } \\
\text { Resources }\end{array}$ & 0.7 & 0.165 \\
\hline & & $\begin{array}{c}\text { Logistics } \\
\text { Technology }\end{array}$ & 0.3 & 0.071 \\
\hline \multirow{5}{*}{$\begin{array}{l}\text { Regional } \\
\text { Logistics } \\
\text { Efficiency }\end{array}$} & \multirow{5}{*}{0.154} & $\begin{array}{c}\text { Logistics } \\
\text { Service } \\
\text { Satisfaction }\end{array}$ & 0.411 & 0.063 \\
\hline & & $\begin{array}{c}\text { The goods } \\
\text { Turnover }\end{array}$ & 0.095 & 0.015 \\
\hline & & $\begin{array}{c}\text { The Logistics } \\
\text { Industry } \\
\text { Status }\end{array}$ & 0.047 & 0.007 \\
\hline & & $\begin{array}{c}\text { Social } \\
\text { Logistics } \\
\text { Capacity }\end{array}$ & 0.235 & 0.036 \\
\hline & & $\begin{array}{c}\text { Social } \\
\text { Logistics } \\
\text { Scope }\end{array}$ & 0.212 & 0.033 \\
\hline \multirow{2}{*}{$\begin{array}{c}\text { The } \\
\text { Regional } \\
\text { Environme } \\
\text { nt }\end{array}$} & \multirow[b]{2}{*}{0.223} & $\begin{array}{c}\text { Degree of } \\
\text { Traffic Load }\end{array}$ & 0.4 & 0.089 \\
\hline & & $\begin{array}{c}\text { Social } \\
\text { Logistics } \\
\text { Pollution }\end{array}$ & 0.6 & 0.134 \\
\hline
\end{tabular}

Step 3: Set up evaluation sets $\mathrm{V}$ and score vector E,as Table III:

TABLE III. THE STANDARD OF INDEX SCORE

\begin{tabular}{|c|c|c|c|c|c|}
\hline Evaluation & $\begin{array}{c}\text { Very } \\
\text { Good }\end{array}$ & Good & Normal & Poor & $\begin{array}{c}\text { Very } \\
\text { Poor }\end{array}$ \\
\hline Value & 5 & 4 & 3 & 2 & 1 \\
\hline
\end{tabular}
WoR.

Step 4: Get the fuzzy evaluation vector, based on $\mathrm{B}=$

$\mathrm{B}=\mathrm{WoR}=(0.4955,0.2851,0.1462,0.0438,0.0290)$

Step 5: Calculate the comprehensive evaluation value.

MakeE $=(5,4,3,2,1)$, so the result is:

$$
\mathrm{S}=\mathrm{EBT}=4.1732 \text {. }
$$

Step 6: Make the conclusion.

The degree of regional logistics sustainable development of city A is good.

\section{CONCLUSION}

This model can reflects the city's regional logistics situation. This data can helps local government to manage and guide the future development direction of logistics enterprises. Making a scientific and systematic comprehensive planning with scientific methods for further micro research to set the scale of logistic industry, hierarchy, and layout, then it can stop the phenomena of redundant construction, waste of resources, environmental damage ${ }^{[8]}$.

\section{REFERENCES}

[1] Changlin Wei and Wei Jia, Analyses our country's Logistics Index[J]. Science and technology communication, 2006,9:47-48.

[2] MinqiuHuang, Research on the Sustainable Development of Regional Logistics[J], Journal of Huaihua University, 2006,25(5):92-98.

[3] ZhaoxiDu and Zhihong Jin, Regional logistics index in the formulation of a preliminary study[J]. Logistics Management, 2009,15:18-21.

[4] Yougu Chen, The Research of the Regional Logistics Sustainable Development on Core Competence. China Circulation Economy[J]. 2006,12:11-14.

[5] Kesheng Liu,Tiening Wang and Jun Huang, Logistics index method research[J]. Logistics Technology. 2003, 8:20-21,37.

[6] Xia Zhu and Xiaofeng Chen,Application of Fuzzy AHP in evaluation of military supplies package scheme[J].Logistics Technology, 2009,28(3):48-151.

[7] Yanmei Zhou and Weihua Li,The improved fuzzy AHP method and its evaluation on the work plan[J]. Computer engineering and Applications, 2008,44(5):212-214.

[8] Liefeng $\mathrm{Yu}$, Logistics park concept of macroeconomic regulation and control research-H index[J]. Logistics Technology. 2011,30(2):63-65. 